EXPERIENCE OF L-ARGININE ADMINISTRATION IN PATIENTS WITH STABLE ANGINA FC III WITH CONCOMITANT HYPERTENSION

N. V. Zozuliak', Z. V. Zozuliak³, V. Ye. Neiko', I. B. Romash', I. R. Romash', I. M. Gayova1, I. V. Tymkiv', M. V. Blyzniuk¹, N. I. Romash ${ }^{1}$ (Ivano-Frankivsk, Ukraine)

1, ${ }^{2}$ SHEE “Ivano-Frankivsk National Medical University”;

${ }^{3}$ Ivano-Frankivsk Central Clinical Hospital. Therapeutic Department No. 2

The aim of the study was to improve treatment of patients with Stable Angina FC III with concomitant Hypertension through a combination of basic therapy with L-arginine. The study involved 63 patients with Stable Angina FC III with Hypertension. In the clinic was made the test with reactive hyperemia, were measured levels of $\mathrm{NO}$ and malonic aldehyde. It was found that in studied patients L-arginine reduces signs of endothelial dysfunction, improves production of nitric oxide and lowers oxidative stress.

Key words: Stable Angina; Hypertension; nitric oxide; L-arginine.

УДК [616.13/.14-031.62]:616.16]-002.18-005.6-002.77]-091.8-036.1 DOI 10.31640/JVD.5-6.2018(16) Надійшла 18.09.2017

V. K. KAZYMYRKO', O. N. NADASHKEVICH', V. E. KLOCHKO', L. M. IVANITSKA', T. S. SILANTIEVA', A. G. DUBKOVA ${ }^{1}$

\title{
STATE OF SMALL VESSELS \\ (INTRA-PARENCHYMAL ARTERIES, ARTERIOLES, CAPILLARIES, VENULES) IN PATIENTS WITH THROMBOANGIITIS OBLITERANS
}

${ }^{1}$ Shupyk National Medical Academy of Postgraduate Education; ${ }^{2}$ City Hospital No1, Bila Tserkva, Kyiv oblast', ${ }^{3}$ Danylo Halytskyi Lviv National Medical University <liliyaivanitska@gmail.com>

The paperaddresses pathological findings in small blood vessels (parenchymal arteries, arterioles, capillaries, venules) of patients with thromboangiitis obliterans. Based on the findings of microcirculation condition in the brain, myocardium, lungs, liver, spleen, kidneys and muscles, we find it advisable to include thromboangiitis obliterans into the Nomenclature of Systemic Vasculitides.

Key words: thromboangiitis obliterans; small vessels; parenchymal arteries; arterioles; capillaries and venules.

In accordance with the ICD-10, thromboangiitis obliterans (Winiwarter - Buerger disease) refers to a group of systemic disorders of connective tissue. It was not included into the 2012 version of the Nomenclature of Systemic Vasculitides [11, 14]. Obviously, the decision was made under the influence of some researchers [3, 18] who consider an acute thrombotic process to be an initial event followed by inflammation of vessel walls. Having analysed the relevant publications [6], we did not find the evidence sound enough to accept this point of view even given the fact that against the background of the gradual disease progression there can occur a severe artery blockage by thrombus, which results in the associated clinical presentation. Some other authors also doubt the leading role of thrombosis in thromboangiitis obliterans (TAO) genesis [17, 25].

This disease primarily affects small arteries and veins of the lower extremities, leading to their occlusion. The causes of the disease, except for the role of smoking, and the pathogenesis remain unknown to date [16]. Productive (proliferative) endo-, meso and periphlebitis occur in the veins of the lower extremities. Similar events are seen in the arteries of the lower extremities. The vessels take the shape of fibrous strands; thickening of the walls in this case is of segmental character. The nature of the morphological changes in the blood vessels depends on the stage of the pathological process [19], as shown in Table 1. 
Table 1. Stage-dependent morphological changes in the vessels in thromboangiitis obliterans

\begin{tabular}{c|l}
\hline \multicolumn{1}{c}{ Stages } & \multicolumn{1}{c}{ Morphological changes } \\
\hline \hline Acute & Alterative-proliferative events (trombovasculitis) occur in the vessels. There \\
& is seen the polymorphonuclear leukocytes (PMN) infiltration into the vascular \\
& walls and perivascular tissue as well as the destruction of the internal elastic \\
& lamina, microabscessation \\
& Mostly productive response. Lymphohistiocytic infiltrates are found in the \\
& wall of the blood vessels, organizing thrombi are seen in the lumen. There are \\
& formed granulomas located in the middle coat of the vessel around the necrotic \\
& fragments of internal elastic lamina and in thrombotic masses. The granulomas \\
& resemble oleogranulomas or tuberculous granulomas \\
& Signs of thrombi organization and total obliteration of the vessels dominate \\
& at this stage. Canalisation and calcification of the thrombi are rather frequent \\
& events
\end{tabular}

The above information shows that TAO refers to the granulomatous pathology. Apparently, ingress of unknown inflammation-inducing antigens into the body is the cause of the disease. Tobacco maybe the source of such antigens. The disease onset is often acute or subacute. The early events in small and medium-sized arteries include mucoid swelling of the adventitia and the intima, as well as plasmorrhagia of the latter [24]. There occurs fibrinoid necrosis of the vessel walls, and diffuse cellular infiltration of all their layers, especially intima, with formation of fibrous deposits, that results in the narrowing of the vascular lumen. A. Abrikosov [1] describes the "focal warty or even polypous inflammatory masses" of the inner coat, leading to the obliteration of the vessel lumen. Dystrophic and destructive events in the endothelium include swelling, vacuolization, karyolysis and desquamation. Inflammatory infiltrates of lymphocytes and macrophages are revealed in all coats (to a lesser extent in the middle and external coats). Apart from the productive process, $20 \%$ of patients develop arteriolo necrosis, fibrinoid necrosis of the vascular walls, neutrophil infiltration [24]. Necrotic foci are replaced by granulation tissueof polymorphocelullar composition sometimes mixed with giant cells. Neutrophils infiltrate thrombi. Microabscessation is seen in thrombi. Granulomas, which are composed of multinucleated giant, epithelioid cells and mononuclear cells, are formed in thrombi and in the middle coat of the vascular wall. A decrease in exudative events is accompanied by the organization of thrombi, the disappearance of microabscesses and survival of small number of giant cells. Thus, the presence of multinucleated, giant and epithelioid cells is indicative of the immune granulomatous inflammation. The similar processes are observed in veins and they result in phlebothrombosis and venous luminal narrowing. Overall, arteritis is concomitant with productive phlebitis and thrombophlebitis. The inflammatory processes in veins and arteries are relapsing. Apart from the involvement of small and mediumsized arteries and veins, microvasculitis, including arteriolitis, capillaritis, venulitis, is seen in all cases. Newly formed vessels, including the v. vasorum, canalized thrombi, vessels of the para-arterial and para-venous bed, skin, muscle stroma, epineurium, perineurium and endoneurium of nerve trunks, become involved in the process [24]. The walls of the arteries with the perivascular tissue, as well as the entire neurovascular bundle are transformed into a dense scar strand, which causes a full occlusion of the arteries. Microangiosclerosis occurs, vessels retract, thus ischemia in TAO arises not only from arterial stenosis, but microangio-, capillary sclerosis.

Arterial stenosis (occlusion) in the extremities occurs after an average of 0.5 year of onset. Loss of the popliteal pulse is seen in $1 / 4$ of patients; $2 / 3$ of patients have loss of pulse on feet and shin. Both men and women are affected by the disease [10]. There is asymmetry in pulse between the paired extremities as well as decreased main blood flow. The concomitant occlusion of the external iliac artery and common femoral artery is often observed. The proximal parts of the vasculature are affected within $2-5$ years from the disease onset. A combined involvementof the proximal and distal parts of the vascular system has been reported in $15 \%$ of patients, with bilateral lesions being 


\section{Table 2. Visceral manifestations of thromboangiitis obliterans}

\begin{tabular}{|c|c|}
\hline Organs & Typical manifestations \\
\hline Skin & $\begin{array}{l}\text { Mottled skin, persistent cyanosis of the distal phalanges of the toes, their } \\
\text { swelling. Digital ulceration and necrosis (in } 70 \% \text { of patients in the advanced } \\
\text { stages of the disease), gangrene of the toes with the possible accession of a sec- } \\
\text { ondary infection. Gangrene of the upper limbsis less frequent than of the lower } \\
\text { limbs ( } 12-15 \%) \text {. There comes skin atrophy. Biopsy shows signs of destruc- } \\
\text { tive-productive vasculitis }\end{array}$ \\
\hline Muscles & $5 \%$ of patientshave myalgia, muscle atrophy occurs \\
\hline Joints & $\begin{array}{l}1 / 5 \text { of patients develop arthralgia, } 1 / 10 \text { of TAO patients have acute transient } \\
\text { migrating non-erosive monoartrita of large joints, spondyloarthropathies, } \\
\text { osteoporosis. Oedema of the ankle joints most often results from the venous } \\
\text { involvement }\end{array}$ \\
\hline CNS & $\begin{array}{l}\text { Prevalence of cerebral disorders is from } 2 \text { to } 30 \% \text {. Polyneuritis, impairment of } \\
\text { cranial nerves, mono- and hemiplegia, intermittent hemiplegia and spasmodic } \\
\text { symptoms are rare. There occur cerebrovascular disorders in various regions of } \\
\text { the brain, dizziness, aphasia, paresthesia, mental disorders, dementia and some- } \\
\text { times episyndrome. There are also seen alternating focal and diffuse damages } \\
\text { to the central nervous system (acute cerebrovascular event, transient ischemic } \\
\text { attack with intermittent hemiplegia) }\end{array}$ \\
\hline $\begin{array}{l}\text { Peripheral ner- } \\
\text { vous system }\end{array}$ & Polyneuropathy \\
\hline Sympathicus & Hyperhidrosis \\
\hline Eyes & $\begin{array}{l}\text { Blood vessels of the retina and other eye tunics are affected; there occur hem- } \\
\text { orrhages in the retina, ischemic optic neuritis, a loss of visual field, impaired } \\
\text { visual acuity }\end{array}$ \\
\hline Heart & $\begin{array}{l}\text { Productive or destructive-productive arteritis of coronary arteries with } \\
\text { secondary thrombosis, endo- and perivasculitis of v. vasorum in the coronary } \\
\text { ostia. The resulting angina is refractory to nitrates. There can occur extensive } \\
\text { myocardial infarction, left ventricular aneurysm, thromboendocarditis, myo- } \\
\text { carditis, increased blood pressure }\end{array}$ \\
\hline Lungs & $\begin{array}{l}\text { Vascular pneumonia, bronchitis (including bronchospastic syndrome), pleural } \\
\text { effusion, pulmonary hypertension, pulmonary heart disease, recurrent pulmo- } \\
\text { nary infarction, pulmonary hemorrhage resulting from festering pulmonary } \\
\text { infarction }\end{array}$ \\
\hline GIS & $\begin{array}{l}\text { Destructive and productive vasculitis of microvessels may result in abdominal } \\
\text { ischemia (intestinal angina), acute abdomen, ulcers, GI bleeding, abscesses, } \\
\text { necrosis of the small intestine and colon, abdominal effusion. Abdominal pain } \\
\text { is often diffuse. At first, the abdomen is somewhat tense but accessible to } \\
\text { palpation with no signs of peritoneal irritation. There is found leukocytosis, } \\
\text { peritoneal irritation, and bowel atony is seen in bowel gangrene. A few days } \\
\text { after thrombosis of the mesenteric veins occurs, bowel necrosis symptoms be- } \\
\text { come prevailing. Involvement of vessels of the stomach, pancreas, liver is rare } \\
\text { and includes symptoms of acute gastric ulcer, gastritis, pancreatitis }\end{array}$ \\
\hline Spleen & Recurrent infarction resulting from thromboembolism \\
\hline Kidneys & $\begin{array}{l}\text { There can occurrapidly progressing glomerulonephritis (proteinuria, hema- } \\
\text { turia), renal artery thrombosis, re-infarction, renal insufficiency. Sometimes } \\
\text { there is pain in kidneys (in the presence of infarcts) }\end{array}$ \\
\hline Genitals & There can occur orchitis, epididymitis, the spermatic cord lesion \\
\hline $\begin{array}{l}\text { Bloodsystem. } \\
\text { Biochemical } \\
\text { changes. Rhe- } \\
\text { ology. }\end{array}$ & $\begin{array}{l}\text { Occasionally the bone marrow is affected and anemia is seen. Hypergamma- } \\
\text { globulinemiy, increased ESR rate, fibrinogen, CRP, sialic acid are common. } \\
\text { There is seen impaired blood rheology (sludge-phenomenon), hypercoagulation }\end{array}$ \\
\hline $\begin{array}{l}\text { General mani- } \\
\text { festations }\end{array}$ & Fever, weight loss are rare ( $5 \%$ of patients) \\
\hline $\begin{array}{l}\text { Aggravating } \\
\text { factors }\end{array}$ & Hypothermia, infections, trauma, antibiotics, alcohol \\
\hline
\end{tabular}


present in $65 \%$ of them. A solitary lesion of the femoral [7], subclavian or axillary artery is rare (5\%). Upper extremities are also affected $[12,16]$. The ulnar artery stenosis occurs in $55 \%$ of patients, the radial artery stenosis is seen in $30 \%$. Arterial involvement of 3-4 extremities is found in 3/4 of patients. Coronaritis usually occurs after the involvenment of the lower extremities. Myocardial infarction can be recurrent with aneurysm formation and thrombosis of the left ventricle. The mesenteric arteries are affected in $5 \%$ of patients. The manifestations include ulcers, necrosis of the intestinal wall, abscesses and abdominal pain [15, 20, 22]. There may also occur thrombosis of the celiac artery and the portal vein. The upper and lower extremities arteries are believed to be affected prior the mesenteric arteries. In $75 \%$ of cases the involvement of mesenteric arteries is combined with migratory phlebitis. $1 / 3$ of the patients develop migrating superficial phlebitis; phlebitis, deep venous thrombosis of the lower extremeties and post-thrombotic disease occur in $18 \%$. Migrating recurrent phlebitis mainly affects the small superficial veins in the upper and lower limbs. It occurs with local pain and flushing of the skin. The veins are dense and painful when pressed. Raynaud's syndrome is observed in $34-57 \%$ of patients with TAO [9, 13]. The nature of visceral TAO manifestations is shown in Table 2.

As Table 2 shows, TAO may result in the involvement of temporal arteries, genitalia [23] joints [8].

It is obvious that the disease-initiating antigens enter not only the vascular walls of the limbs, but various internal organs vessels including arterioles, capillaries, and venules. It should be noted that the relevant publications on issues of visceral lesions, generalization of pathological processes in TAO focus mainly on medium-sized arteries. The events occurring in the arterioles, capillaries and venules of the internal organs have been understudied. The generalization of the process primarily involves cerebral and cardiac vessels [19]. Systemic lesions of the arterial bed (generalization of the process), which is observed in some TAO cases, are similar to those found in nodular polyarteritis. The following clinical cases show some pathological changes found in the small vessels of various organs in TAO patients. Ya. Patient, born in 1949, was transferred from endocrinology to cardiology department of Hospital No1, city of Bila Tserkvaat $11: 50$ a. m., 5/7/2002. His condition was of moderate severity. He believed to have been ill for 1 year. In his opinion the disease developed after swiming in the river, the body temperature rose to $39^{\circ} \mathrm{C}$. On admission he was diagnosed with polymyositis, a subacute course; Susp. Neo, AIDS, differentiation with Winiwarter - Buerger disease as in 2001 the patient was diagnosed with obliterating endarteritis, acute thrombophlebitis of the left thigh. The patient suffered from pain in the shoulder, knee joints, marked weakness in the proximal parts of the limbs, generalized weakness, fever up to $39^{\circ} \mathrm{C}$. The lab examination revealed anemia $\left(\mathrm{RBC}-2.2 \cdot 10^{12} / \mathrm{l}\right.$, Hgb $-65 \mathrm{~g} / \mathrm{l}$, WBC $-30.7 \cdot 10^{9} / \mathrm{l}$, ESR $-65 \mathrm{~mm} / \mathrm{h}$ ), leukocyturia (25-30 per field of view), blood glucose $-6.6 \mathrm{mmol} / \mathrm{l}$, total protein $-53.2 \mathrm{~g} / \mathrm{l}, 50 \%$ albumin, gamma globulin $25 \%$, prothrombin index $-80 \%(12 / 7 / 2002-63 \%)$, elevated blood fibrinogen (on admission $-2.5 \mathrm{~g} / \mathrm{l}$, on $9 / 7 / 2002-7 \mathrm{~g} / \mathrm{L}$ ), creatinine -0.123 , ALT -1.6 , AST $-1 \mathrm{mmol} / \mathrm{l}$. Rose - Waaler test was positive at a dilution of $1: 8$. Blood culture was negative. Gregerson'stest of vomiting matter was negative. Ultrasound investigation revealed free fluid in the abdominal cavity. After the examination, the patient was diagnosed with Winiwarter-Buerger disease (thromboangiitis obliterans), a subacute course, visceral-peripheral type with the involvement of the heart, joints (arthritis); polyneuropathy. Against the background of conservative therapy (prednisolone, dexamethasone, diclofenac, pentoxifylline, sinkumar, antibiotics) the patient's condition was moderate. On 13/7/2002 there appeared nausea, vomiting, and then the patient fell into a coma. Neurological examination revealed cerebral edema. At 3.20 p. m. the same day the patient died. The final clinical diagnosis: Principal: Winiwarter - Burger disease (thromboangiitis obliterans), a subacute course, visceral-peripheral type with theinvolvement of the nervous system (cerebral thrombosis), kidneys, gastrointestinal tract heart and joints. Complications: Haemorrhage in the pons, mesenteric arterial thrombosis. Severe Anemia. Susp. Neo. 
Post-mortem diagnosis: Principal: Winiwarter - Burger disease (thromboangiitis obliterans). Complications: multiple hemorrhages in the brain, piar mater, under the pleura, in the heart and lungs. Cerebral edema. Pulmonary edema. Histologic findings in the brain included: intravascular sludging of red cell in the microcirculatory blood flow, neutrophilic thrombi with microabscession in some vessels; prolonged thrombosis in some small arteries, swelling of endothelium, infiltration of the vascular walls with lymphoid cells in other blood vessels; the vast area of hemorrhage with segmental leukocytes and lymphoid cells infiltration; resorptive lesions of the brain matter in the periphery of the hematoma. Oedematous pial membranes; perivascular oedema, degeneration of neurons.

Histologic finding in the myocardium: some vessels in microvasculatory blod flow and arterioles showedmarked intravascular deposition of neutrophilic leukocytes with fibrinoid necrosis of the vascular walls and infarction zones development with segmented leukocytes infiltration in the perifocal areas. Severe interstitial oedema, granular and vacuolar degeneration of cardiomyocytes focal fragmentation of muscle fibers.

Histologic finding in the lungs: intravascular erythrocyte stasis, sludge-phenomenon, deposits of segmented leukocytes in places with the endothelium desquamation and focal fibrinoid necrosis of the walls; focal infiltration of intraalveolar septa with lymphomacrophagal elements; protein-containing liquid with admixted cells of the desquamated alveolar epithelium and erythrocytes within the alveolar lumeni; dystelectatic foci.

Histologic finding in the kidneys: white thrombi, necrosis of the vascular wall and perifocal abscession in individual venous vessels;focal membranous glomerulitis, fibroplastic changes of glomeruli in places; granular dystrophy of tubular epithelium with focal necrobiosis; papillary adenoma in the cortical area;focal periglomerular and perivascular lymphomacrophagal infiltrates in the interstitial tissue.

Histologic finding in the liver: discoupling of hepatic beams, granular degeneration of hepatocytes, expended Disse's spaces against the background of the organ plethora; lymphoid infiltration of the triads.

Histologic finding in the spleen: depletion of lymphocytes fromB-dependent zones with lack of follicular structures but preservation of T-dependent areas; fibrinoid necrosis of the arterioles. The pathologists concluded that the patient had had a visceral form of thromboangiitis obliterans involving small and medium - sized arteries, veins and other vessels of the microcirculatory bed of the brain, myocardium, lungs and kidneys. Destructive and proliferative systemic vasculitis with formation of neutrophilic thrombi, microabscession with perifocal tissue infiltration is a morphological marker of this process. It seems to be the main morphological feature of TAO. Impaired cerebral circulation due to the underlying disease turned out to be a key factor in the tanatogenesis.

Difficulties associated with Winiwarter - Burgess disease diagnosing were found while studying another similar case.

In that case pathologists concluded that the patient had had a visceral form of thromboangiitis obliterans involving small and medium-sized arteries, veins and other vessels of the microcirculature of the lower limbs, myocardium, lungs, severe damage to the kidneys and liver. It was noted that destructive and proliferative systemic vasculitis with formation of neutrophil thrombi as more frequent event, microabscession and perifocal tissues infiltration was a morphological marker of this process. Renal failure was a leading eventin tanatogenesis. It resulted from diffuse proliferative and membranous glomerulonephritis, which should be regarded as one of the visceral manifestations of the underlying disease.

A. Abrikosov and Nobl as early as in 1933 [1] classified TAO as allergic conditions resulting from the prior sensitization. Mucoid swelling of the connective tissue fibers with fibrinoid transformation and a futher productive inflammatory reaction is characteristic of a morphological picture of allergic (hyperergic) changes. Post-mortem histological studies of the various organs of TAO patients are indicative of the fibrinoid necrosis of the microvasculature (Table 3 ). 
Table 3. Status of the microvasculature in thromboangiitis obliterans patients based on histological data

\begin{tabular}{|c|c|}
\hline Organ & Pattern of morphological changes \\
\hline Cerebrum & $\begin{array}{l}\text { Perivascular oedema, plasmorrhagia and fibrinoid swelling of the vascular } \\
\text { walls, sludging of erythrocytes. Thrombosis of small arteries, neutrophilic } \\
\text { thrombi with microabscesses. Multiple hemorrhages }\end{array}$ \\
\hline Myocardium & $\begin{array}{l}\text { Lymphocyte infiltration of the microvascular walls, fibrinoid necrosis, neu- } \\
\text { trophils deposition within the lumen. Developmentof infarction zones in the } \\
\text { perifocal areas with segmental leukocyte infiltration. Perivascular sclerosis } \\
\text { with lymphoid infiltration }\end{array}$ \\
\hline Lungs & $\begin{array}{l}\text { Erythrocyte stasis within the vascular lumen, sludging, deposition of } \\
\text { segmental leukocyte with endothelial desquamation and focal fibrinoid necro- } \\
\text { sis of the wall. Lymphomacrophagal infiltration of intraalveolar septa. Focal } \\
\text { subpleural hemorrhage }\end{array}$ \\
\hline Liver & $\begin{array}{l}\text { Lymphoid infiltration of the portal tracts. Giant cell hepatitis. Interstitial } \\
\text { fibrosis with marked lymphomacrophagal infiltration of portal tracts }\end{array}$ \\
\hline Spleen & $\begin{array}{l}\text { Fibrinoid necrosis of the arterioles. A loss of lymphocytes from B- dependent } \\
\text { areas but survival (preservation) of T-dependent areas or a loss of lympho- } \\
\text { cytes from B- and T-dependent areas with absence of follicular structures }\end{array}$ \\
\hline Kidneys & $\begin{array}{l}\text { Severe vasculitis with sclerosis of vascular walls and lymphomacrophagal } \\
\text { infiltration around veins and arteries of various sizes. White thrombi with } \\
\text { necrosis of the vascular wall and perifocal abscession within the lumen of } \\
\text { individual venous vessels. Focal membranous glomerulitis with fibroplastic } \\
\text { glomerular changes in places. Diffuse membranous-productive intra- and } \\
\text { extracapillary glomerulonephritis with focal fibrinoid necrosis of glomerular } \\
\text { capillary loops. Focal periglomerular and perivascular lymphomacrophagal } \\
\text { infiltration, periglomerular sclerosis in the interstitial tissue. Granular dystro- } \\
\text { phy of tubules epithelium, focal necrobiosis }\end{array}$ \\
\hline $\begin{array}{l}\text { Cross-striated } \\
\text { muscle }\end{array}$ & Lymphocytic infiltrates, focal fibrinoid necrosis of vessels, their hardening \\
\hline
\end{tabular}

Development of TAO should be associated with hypersensitivity presumably to some component of tobacco. Sensitized T- lymphocytes secrete lymphokines that inhibit the migration of macrophages, promoting their concentrating at sites of antigens deposition. The macrophages are activated; they secrete a variety of cytokines, lysosomal enzymes that damage the vascular wall. Thus granulomas develop. If endothelial cells are damaged, IL-8, IL-1 and endothelin are released. Neutrophils are activated (by IL-8), platelet aggregation increases, vascular occlusion and vasoconstriction (endothelin impact) occur, the above cytokines support the immune inflammation of the vascular wall $[2,21]$.Vasculitis is of granulomatous-necrotizing nature with the involvement of the arterioles, venules, capillaries. Granulomatous inflammation is seen in vascular walls and perivascular spaces. The above clinical cases are indicative of the generalization of the pathological process in TAO. Our clinical observations show that the generalization of TAO is often accompanied by pain in muscles and joints, a cough with a moderate amount of mucous or muco-purulent and even bloody sputum, a picture of bronchitis, pneumonia, pleurisy, ascites, an augmentation of pulmonary heart failure, renal disease symptoms (hematuria, proteinuria, renal failure), anemia, neutrophilic leukocytosis, a significant increase in blood fibrinogen and ESR.

Multinucleated giant and epithelioid cells, which are markers of an immune mechanism of granulioma formation, are revealed in inflammatory granulomas in TAO. The granulomas are based on a delayed-type hypersensitivity (DTH) reaction, which does not exclude the involvenment of immediate-type hypersensitivity (GNT). These processes can alternate, just as it is seen in Wegener's disease. On the whole, TAO is a hypersensitivity granulomatous disease whose antigen still remains unknown. In this case, the delayed-type allergic reactions are mediated not by humoral antibodies but cells, primarily by T-lymphocytes. Cellular reactions of a delayed type are responsible for immunological surveillance of the 
antigenic composition of the body. The course of TAO is chronic, undulating. The immune inflammation is known to have a tendency to a self-replicate and continuous course with varying duration of exacerbation and attenuation alternating each other [2, 4]. Liquid white and yellow pasty mass that resembles pus is detected in the center of vascular thrombi in TAO patients. In fact, this process is aseptic puruloid softening, which can be considered as coagulative necrosis with the transition to colliquative [5]. Aggregates of fused blood cells predominate in agglutinative thrombi. Thrombi are soldered to the vascular wall. They are stratified. Nneutrohils and platelets deposits are seen in the fibrin network. Thrombi development results from a decrease in antithrombogenic properties of the vascular wall, i. e. its damage. As can be seen from the above, thrombi formation in the vessels in TAO is a secondary process, a consequence of inflammation.

Conclusions. 1. Thromboangiitis obliterans is a systemic pathology in which the productive-destructive processes involve not only medium-sized, but also small vessels (parenchymal arteries, arterioles, capillaries and venules). 2. Destructive and proliferative systemic vasculitis with formation of neutrophil thrombi having puruloid aseptic softening in their core is a morphological marker (the main morphological feature) of the disease. 3. The development of immune granulomatous inflammation in the vascular walls is characteristic of Winiwarter - Burgess diseases. The presence of multinucleated giant and epithelioid cells in granulomas provides evidence of the immune nature of inflammation. 4. Thrombus formation in the vessels in TAO is a secondary process resulting from the primary inflammation, and there is every reason to include TAO in the nomenclature of systemic vasculitis.

\section{References}

1. Абрикосов А. И. Частная патологическая анатомия // Сердце и сосуды. Вып. II. Л.-М.: Медгиз, 1953. - 407 с.

2. Васкулиты //Внутренниеболезни по Тинсли Р. Харрисону / Под ред. Э. Фаучи, Ю. Браунвальда, К. Иссельбахера, Дж. Уилсона, Дж. Мартина, Д. Каспери, С. Хаузера и Д. Лонго. В 7 т. Кн. 5. - М.: Практика, 2005. - 2036 с.

3. Вест С.Дж. Секреты ревматологии. - СПб: Невский Диалект, 1999. - 768 с.

4. Дамианов И. Секреты патологии : Пер. с англ. - М.: ООО «Медицинское информационное агентство», 2006. - 600 с.

5. Зербіно Д. Д., Зімба О. О., Багрій М. М. та ін. Облітераційний тромбангіїт (хвороба Бюргера): особливості діагностики та лікування // Серце і судини. - 2016. Вип. 53, № 1. - С. 99-106.

6. Новиков П. И., Семенкова Е. Н., Моисеев С.В. Современная номенклатура системных васкулитов // Клин. фармакология и терапия. - 2013. - Вып. 22, № 1. - С. 70-74.

7. Ревматология:национальноеруководство / Под ред. Е. Л. Насонова, В. А. Насоновой. М.: ГЭОТАР-Медиа, 2008. - 720 с.

8. Семенкова E. Н. Системные васкулиты. М.: Медицина, 1988. - 240 с.

9. Струков А. I., Серов В. В. Патологічна анатомія. - Харків: Факт, 1999. - 846 с.

10. Ярыгин Н. Е., Шилкина Н. П., Романов В. А., Лилелева М. А. Морфологические критерии облитерирующего тромбангиита и атеросклероза сосудов нижних конечностей // Терапевт. арх. - 1990. - № 10. - С. 122-125.
1. Abrikosov A. I. CHastnaya patologicheskaya anatomiya // Serdce i sosudy. Vyp. II. L.-M.: Medgiz, 1953. - $407 \mathrm{~s}$.

2. Vaskulity // Vnutrennie bolezni po Tinsli R. Harrisonu / Pod red. Eh. Fauchi, Yu. Braunval'da, K. Issel'bahera, Dzh. Uilsona, Dzh. Martina, D. Kasperi, S. Hauzera i D. Longo. V 7 t. Kn. 5. - M.: Praktika, 2005. - $2036 \mathrm{~s}$

3. Vest $S$. Dzh. Sekrety revmatologii. - SPb: Nevskij Dialekt, 1999. - 768 s.

4. Damianov I. Sekrety patologii : Per. s angl. M.: OOO «Medicinskoe informacionnoe agentstvo», 2006. $-600 \mathrm{~s}$.

5. Zerbino D. D., Zimba O. O., Bagrij M. M. ta in. Obliteracijnij trombangiït (hvoroba Byurgera): osoblivosti diagnostiki ta likuvannya // Serce i sudini. - 2016. - Vip. 53, № 1. S. 99-106.

6. Novikov P. I., Semenkova E. N., Moiseev S. V. Sovremennaya nomenklatura sistemnyh vaskulitov // Klin. farmakologiya i terapiya. - 2013. - Vip. 22, № 1. - S. 70-74.

7. Revmatologiya: nacional'noe rukovodstvo / Pod red. E. L. Nasonova, V. A. Nasonovoj. M.: GEHOTAR-Media, 2008. - 720 s.

8. Semenkova E. N. Sistemnye vaskulity. - M.: Medicina, 1988. - $240 \mathrm{~s}$

9. Strukov A. I., Serov V. V. Patologichna anatomiya. - Harkiv: Fakt, 1999. - 846 s.

10. Yarygin N. E., Shilkina N. P., Romanov V. A., Lileleva M. A. Morfologicheskie kriterii obliteriruyushchego trombangiita i ateroskleroza sosudov nizhnih konechnostej // Terapevt. arh. - 1990. - № 10. - S. 122-125. 
11. Abhishek Vijayakumar, Rahul Tiwari, and Vinod Kumar Prabhuswamy Thrombangiitis obliterate (Buerger's Disease) - Current Practices / Internat. J. of Inflammation. - Vol. 2013. - N 3. - P. 9.

12. Ahtem Ruchan Akar, M. Bahadir Inan, Cagdas Baran. Thrombangiitis Obliterans // Vasculitis (P Seo, Section Editor). - Curr Treat Options in Rheum. - 2016. - Vol. 2. - P. 178-195.

13. Federico Bucci, Adriano Redler, Leslie FiengoCritical limb ischemia in a young man: Saddle embolism or unusual presentation of Thrombangiitis Obliterans? // Case reports in vascular medicine. - 2013. - N 2. - P. 4.

14. Göçen U., Atalay A., Deniz L. Succesfull multidisciplinary treatment in a case of Buerger // J. Cardiovasc. Dis. Res. - 2013. - Vol. 4. - P. 198-200.

15. Hartmann P., Mohokum M., Schlattaman P. The association of Raynaud syndrome with thromboangiitis obliterans-a meta-analysis // Anthology. - 2012. - Vol. 63, N 4. - P. 315-319.

16. IgnacioJ. Rivera-Chavarria, Jose D. Brenes-GutierrezThromboangiitis obliterans (Buerger's disease) // Ann. of Med. and Surgery. - 2016. - Vol. 7. - P. 79-82.

17. Iwai T., Sato S., Kume H. et al. Clinical Study of Phlebitis Migrans and Incompetence of the Leg's Superficial Vein in Buerger Disease // Ann. of Vascular Diseases. - 2012. - Vol. 5, N 1. - P. 45-51.

18. Jennete I., Falk R., Bacon P. et al. Revised international Chapel Hill consensus conference nomenclature of vasculitides // Arthritis. Rheum. - 2012. - Vol. 65. - P. 1-11.

19. Liew N., Lee L., Hanipah N. et al. Pathogenesis and management of Buerger's disease // Int. J. Low. Extrem. Wounds. - 2015. - Vol. 14, N 3. - P. 231-235.

20. Malecki Rafal, KluzJoanna, Przedziecka-DolykJoanna, Adamiec Rajmund. The Pathogenesis and Diagnosis of Thrombangiitis obliterans: Is it Still a Mystery?// Adv. Clin. Exp. Med. - 2015. Vol. 24, N 6. - P. 1085-1097.

21. Niclauss L., Roumy A., Gersbach P. Spinal cord stimulation in thromboangiitis obliterans and secondary Raynaud's syndrome // Eur. J. Vasc. Endovasc. Surg. - 2013. - Vol. 36. - P. e9-e11.

22. Peter F. Klein-Weigeland Jutta G. Richt. Thromboangiitis obliterans (Buerger's disease) // Vasa. - 2014. - Vol. 43. - P. 337-350.

23. Ryn S. -W.,Jeon H. -J., Cho S. -S. et al. Treatment of digit ulcers in a patient with Buerger's disease by using cervical spinal cord stimulation // Korean J. Anesthesial. - 2013. - Vol. 65, N 2. - P. 167-171.

24. Sun X-l., Law BY-K., de Seabra Rodrigues Dias I. R. et al. Pathogenesis of thromboangiitis obliterans: Gene polymorphism and immunoregulation of human vascular endothelial cells // Atherosclerosis. - 2017. - N 3. - P. 78-95.

25. Weingartner K., Gerharz E. W., Kohl U. et al. Fokale nekrotisierende vasculutis des hodens. Testikulare manifestationen immunologischer erkrankungen in der differential- diagnostik des hodentumors // Urologe. - 1994. - Vol. 33. - P. 320-324.

\section{СТАН ДРІБНИХ СУДИН (ВНУТРІШНЬОПАРЕНХІМАТОЗНІ АРТЕРІЇ, АРТЕРІОЛИ, КАПІЛЯРИ, ВЕНУЛИ) У ХВОРИХ НА ОБЛІТЕРУЮЧИЙ ТРОМБАНГІЇТ}

\section{В. К. Казімірко, О. Н. Надашкевич, В. С. Клочко, Л. М. Іваніцька, Т. С. Сілантьєва, А. Г. Дубкова (Київ, Біла Церква, Львів)}

У статті описано патологічні зміни, що розвиваються в дрібних судинах (паренхіматозні артерії, артеріоли, капіляри, венули) хворих на облітеруючий тромбангіїт. Грунтуючись на результатах дослідження стану мікроциркуляції в головному мозку, міокарді, легенях, печінці, селезінці, нирках і м'язах, вважаємо за доцільне внести облітеруючий тромбангіїт до номенклатури системних васкулітів.

Ключові слова: облітеруючий тромбангіїт; дрібні судини; паренхіматозні артерії; артеріоли; капіляри; венули.

\section{СОСТОЯНИЕ МЕЛКИХ СОСУДОВ (ВНУТРИПАРЕНХИМАТОЗНЫЕ АРТЕРИИ, АРТЕРИО- ЛЫ, КАПИЛЛЯРЫ, ВЕНУЛЫ) У БОЛЬНЫХ ОБЛИТЕРИРУЮЩИМ ТРОМБАНГИИТОМ}

\section{В. К. Казимирко, О. Н. Надашкевич, В. Е. Клочко, Л. Н. Иваничкая, T. С. Силантьева, А. Г. Дубкова (Киев, Белая Церковь, Львов)}

В статье описаны патологические изменения, развивающиеся в мелких сосудах (паренхиматозные артерии, артериолы, капилляры, венулы) больных облитерирующим тромбангиитом. Основываясь на результатах исследования состояния микроциркуляции в головном мозге, миокарде, лёгких, печени, селезёнке, почках и мышцах, считаем целесообразным включить облитерирующий тромбангиит в номенклатуру системных васкулитов.

Ключевые слова: облитерирующий тромбангиит; мелкие сосуды; паренхиматозные артерии; артериолы; капилляры; венулы. 